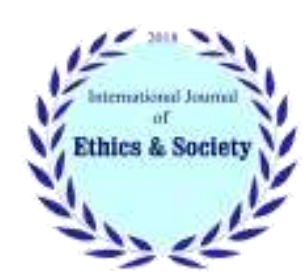

International Journal of Ethics \& Society (IJES)

Journal homepage: $\underline{\text { www.ijethics.com }}$

Vol. 3, No. 1 (2021)

\title{
The Role of Organizational Silence \& Organizational Mobbing on the Turnover Intention
}

\author{
Bahman Saeidipour $^{a^{*}}$, Peyman Akbari ${ }^{b}$, Zahra Alizade ${ }^{a}$ \\ a) Dept. of Education Science, Payame Noor University, Iran. \\ b) Dept. of Management, Payame Noor University, Iran.
}

\section{Abstract}

Background: The main purpose of this study was to analyze the impact of organizational silence and mobbing on turnover intention.

Method: The statistical population of this study was 386 employees of Payam-e-Noor University of Kermanshah. In order to determine the sample size we have applied Morgan table and consequently 191 employees have were selected as sample members by random sampling method for the first half of 2018. The data collection tool was a standard questionnaire in this area. Validity (content, convergent, divergent) and reliability (loading factor, composite reliability, Cronbach's alpha) of questionnaire indicate that measuring instruments have good reliability and validity. The results of hypotheses test by SMART-PLS software and using t-test statistics.

Results: Path coefficients $(\beta)$ indicate that organizational silence have strong, direct and significant influence on mobbing. Mobbing have strong, direct and significant effects on turnover intention and organizational silence have weak, indirect and significant effects on turnover intention. On the other hand, mobbing can play moderator role in influence on organizational silence and turnover intention.

Conclusion: Despite the design model, it can be expected that the university can reduce the level of job leave due to the variables of organizational silence and organizational mobility.

Keywords: Organizational silence, Organizational mobbing, Turnover intention.

\section{Introduction}

Today, many organizations and companies pay attention to methods and tools such as teamwork, organizational democracy, and strengthening the culture of organizations in order to achieve success.
This will allow employees to not be silent at work and to express their ideas and share their knowledge to achieve a desired success in reducing turnover

*Corresponding Author: Email: Bahman_saeidipour@yahoo.com

Received: 3 Jan 2021

Accepted: 10 Feb 2021 
intention. Therefore, creating such an organizational space is very important for any organization and company. On the other hand, many employees prefer to be silent in the place, and this silence depends on various factors, such as the fear of losing a job, lack of opportunity to express their ideas to management and other cultural values. Of course, environmental and organizational factors, and team management can also create a supportive atmosphere for organizational silence (1). Studies have summarized two reasons for silence. The first reason includes: fears and suspicions, fear of being labeled or stigmatized or viewed negatively, fear of losing contact, feelings of emptiness, fear of punishment, and fear of other negative factors. The second reason is related to individual (lack of experience, lack of interest) and organizational characteristics (structural and cultural hierarchy, lack of support) or poor relationship with department management and differences between them (2). Organizational silence can cause certain problems for organizations. According to the lack of feedback, silence has a negative effect on the decision-making process, learning and change at the organizational level. On the other hand, at the individual level in employees, it can create a feeling of emptiness, lack of control and anomalies (such as mobbing) in the organization (1). In other words, it might be said; the reason for the formation of these types of anomalies is due to the decision-making process, correction of mistakes and innovation in the method of organizational silence, which its amount is low. However, in addition to the fact that silence will have adverse effects on the individual, organizational and even social sectors, it must be properly identified what causes the bullying behavior. Researchers have also rightly found that such behaviors can be classified into forms, such as, attacks on personal social relationships, attacks on individual reputation, attacks on the quality of one's personal profession and living conditions, and damaging the personal health. Hooliganism will cause certain problems in organizations, such as increasing the tendency to leave the job, which in turn causes irreparable damage to the efficiency and performance of the organization (3). To this end, in order to increase job satisfaction and improvement of performance of employees and ultimately reduction the job leave, the mobster behavior of employees should be reduced (4). Because organizations spend a lot of money on training employees, they should try not only to prevent employees from leaving their jobs, but also to be able to reduce their bullying behavior by training team dynamics, synergizing activities to achieve goals, lead employees to high productivity and performance (5).

Therefore, understanding the role of organizational silence and organizational mobility on the desire to leave the job is one of the important issues of organizations. Because to reduce employee layoffs, the manager must try to reduce bullying behavior and organizational silence. Therefore, researchers in this study, according to the purpose of this study, which is to explain the role of organizational silence and organizational mobility on the desire to leave the job, seek to answer the question of whether organizational silence and organizational mobility have effect on the tendency to leave the job (Case study: Payam-e-Noor University of Kermanshah)?

Theoretical literature and research background Organizational silence and organizational mobbing (Suppress)

Performance is the level of work accomplished in the organization, and when an employee is under pressure in the organization, he or she will exhibit behaviors that reduce his or her level of performance. Those behaviors are called organizational mobbing (6). In such a situation, two costs (both for the organization and the employee) are conceivable. First, an employee who continues to be a mobbing becomes physically and mentally ill over time, and if medical leave is taken for such an illness, the organization is forced to pay him or her despite his or her absence from the organization. Secondly, if the person recovers, he or she will no longer perform as tangibly as in the past (7). Therefore, to achieve the organizational goals it is better that the organizational be far from mobbing behaviors, and a way to control such behaviors is the organizational silence. The organizational silence means the purposeful silence of an employee who does not present his ideas, knowledge and opinions about improving the work environment. Of course, 
constantly preventing such behaviors from employees in the long run lead to the detriment of the organizational system (8). Therefore, such behaviors in the universities should be considered because, in addition to its positive effects on students, it will also have negative effects on them and damage the educational environment (9). Finally, it must be possible to maintain organizational silence against mobbing at its desired level. Some researchers such as $(10,11,12$, and 13) have conducted research in this regard and suggested the optimal level of organizational silence against mobbing. Therefore, in the end, according to what has been said, it should be said that the first hypothesis is as follows:

"Organizational silence has an effect on organizational mobbing."

\section{Organizational mobbing and turnover intention}

There is relatively limited research on the relationship between pressure and the tendency to quit, and most of this researches also covers employee health. What stands out most in these studies are the terms "imposition" and "pressure". Pressure in the workplace is a word that means resisting the unwanted and negative actions of an individual or group. They (workers) end up defending themselves with seduction and struggle, resulting in an equivalent balance of power and strength at work (14). Pressure is achieved as a definite result of a profit, quality and voluntary performance. Applying pressure is defined as a simultaneous effect of an action between the target person and its imposition on the tendency of the person to leave his job (15). A study in workers' health has shown that putting pressure has a direct effect on the tendency to quit, as it increases the tendency of people to quit their jobs. It is sometimes stated that the purpose of these pressures is to replace employees with each other (14). The effect of pressure from superiors is greater than pressure from colleagues, and in this case the range of tendency to leave the job will increase $(16,17)$.

Therefore, in the end, according to what has been said, it should be noted that the second hypothesis is as follows:

"Organizational mobbing has an effect on turnover intention."

\section{Organizational silence and turnover intention}

The turnover intention means that employees are likely to leave the job as they wish and away from the view of the organization (18). When a person's desire increases, the amount of work will decrease and, of course, the absence of people will be prolonged, and such conditions will have irreparable effects on the physiological, social, and economic needs of people. Perhaps this is why researchers want more research in this regard (19). Organizational silence is one of the most important factors that can affect turnover intention to reduce its negative side. Organizational silence is a behavioral issue and occurs when a group of people are unable to express their thoughts and ideas that prevent poor performance and improve organizational performance (20). This type of behavior has been experienced in most organizations and the results indicate that the silence factor is sensitive. Because it has created an environment in the organization that employees have resorted to silent behaviors for various reasons. The term was first used by some researches, and its meaning is the absence of speech (21). However, some researches considers the opposite of organizational silence as organizational voice. In this case, people will be able to choose when to be silent or when to have an idea. But, in organizational silence, creative ideas do not occur, and the team perspective is considered natural, and this is a possible reason for organizations to find solutions to problems (22). If it becomes individual behavior, it can create an effective new environment (23). Therefore, management has an important role to play in understanding silence. The culture created by management requires the participation of employee products. Managers must try to create a safe environment for workers. In organizations, while organizational silence causes dissatisfaction among employees, it also leads to the formation of incorrect and unequal communication and unwanted behaviors. As a result, it generally degrades the performance of organizations. Numerous related studies have described silence as activeness and purposeful behavior. Although the understanding of silence in organizations is initially considered as a sign of loyalty (2), but the general pur- 
pose intentionally refers to the maintenance of negative issues and problems by employees, and in the end it should be said that little research, including $(12,24-30)$ deals with the relationship between organizational silence and the desire to leave the job. Therefore, in the end, according to what has been said, it should be note that the third hypothesis is as follows:

"Organizational silence has effect on the turnover intention."

The mediating effect of Organizational mobbing on the impact of organizational silence on turnover intention

Workplace pressure involves a series of systematic emotional attacks that target specific individuals (31). Mobbing has recently increased in organizations. In working life, pressure is considered in the form of approaches such as fear and intimidation and a specific process for an individual or a group of people. In general, these factors are invisible. But sometimes oppressive practices cause active employees to become inactive and then dismissed from office positions. Mobbing is defined as the act of putting physiological pressures on individuals that cause a person to lose his or her personality as an employee in a cruel and stubborn manner (32). There is a lot of disagreement in organizations where mobbing is applied. Also, in these organizations, the comfort and convenience of people is greatly reduced and employees are looking for a way to escape. As a result, people do not feel a sense of belonging to their organization. So, they lose their desire to stay in the organization and seek work with better conditions (31). These behaviors cause employees to not only feel uncomfortable, but also to lose their creativity towards work and the organization.
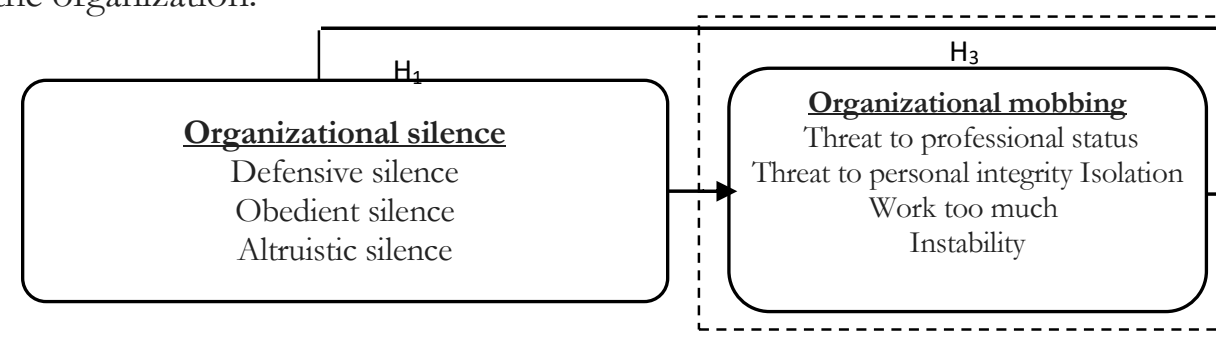

$\mathrm{H}_{4}$

Fig. 1: Conceptual model of research
Health problems are caused by stress $(33,34)$. Other researchers such as some researches (35) have researched physiological and physical problems. Applying pressure causes nervous problems (36). Applying pressure reduces employee motivation and creativity (37). Applying pressure increases medical expenses, weakens motivation and reduces production. Such circumstances, as mentioned, cause the trained employees of the factory to leave their organization and as a result, the organization loses the experience of such employees and its training and other legal expenses will increase in the future. Pressure occurs when a person is systematically exposed to hostile behavior by one or more of their co-workers at a specific time. In this case, the employee is defending himself. In this case, severe physiological shocks are inflicted on him. Applying pressure means coercion and oppressive orders on employees and therefore has negative consequences for organizations and their employees (38). It has sometimes been observed that victims and people targeted by pressure tend to increase organizational silence, and this silence reflects their reaction (39). However, limited research $(12,40)$ have examined the effect of exerting pressure on the relationship between organizational silence and the tendency to leave the job.

Therefore, in the end, it should be say that the fourth hypothesis is as follows:

"Organizational mobbing plays a mediating role in the effect of organizational silence on turnover intention."

According to the theoretical foundations and hypotheses of the research, the model of research concept was developed as follows (Figure 1). This pattern shows the relationship between research variables: 


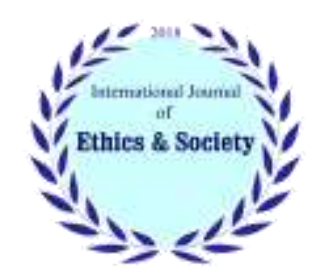

\section{International Journal of Ethics \& Society (IJES) \\ Journal homepage: www.ijethics.com \\ Vol. 3, No. 1 (2021)}

\section{Material \& Methods}

This is an "applied research" study and it is a "descriptive research" in terms of data collection. Since researchers sought to determine the relationship between variables, this is a "solidarity research". The statistical population in this study, according to the research variables, was all employees of Payame Noor University in Kermanshah with 381 people. The sample size was 191 people that were obtained through Morgan table and people are selected by random. The main tools of data collection were as follows: Dostar and Ismailzadeh's organizational silence questionnaire (41) that consists of 13 questions. Pranjić et al. organizational mobbing questionnaire (42) that consists of 19 questions. Elçi et al. turnover intention questionnaire (12) that consists of 3 questions. The measurement scale of the ideas was based on the five-item Likert scale that starts from "strongly disagree" and ends with "strongly agree". The scoring of questions is calculated from score 1 to score 5 . To confirm the validity of the measurement tool, three types of assessment validity were used: content validity, convergent validity and divergent validity. The content validity is created by ensuring compatibility between the measured parameters and the existing literature. This validity was obtained by a survey of faculty members. Convergent validity refers to this principle that indicators of each structure have moderate correlation with each other. According to [43], the convergent validity criteria is that Average Variance Extracted (AVE) is greater than 0.05. Divergent validity is also measured by comparing the square root of AVE with the correlation between latent variables (table 2). Also, for each reflective constructs, the square root of AVE should be more than the correlation of that structure with the other structures in the model. Also, in this study, two criteria (Coefficient of Cronbach's alpha, combined reliability coefficient and Coefficient of composite reliability) were used to determine the reliability of the questionnaire (43). Coefficients of Cronbach's alpha and combined reliability coefficient for all variables in this study are greater than the minimum amount of (0.70). The composite reliability is based on the real loadings factors of each structure unlike Cronbach's alpha which implicitly assumes that each index has the same weight. So, it presents better criteria for reliability. The composite reliability should be a value greater than 0.70 to represent the internal stability of the structure. In tables 1 and 2, the reliability and validity results of the measurement tool are given completely.

Based on the contents and the results obtained from the outputs of SMART-PLS software in tables 1 and 2, it shows that the tools for measuring validity (content, convergent, divergent) and reliability (Loadings factors, composite reliability coefficient, Cronbach's alpha coefficient) are appropriate.

\section{Table 1: Convergent validity and reliability of measurement tools}

\begin{tabular}{c|c|c|c|c|c|c|}
$\begin{array}{c}\text { Cronbach's } \\
\text { alpha }\end{array}$ & Rho_A & C r c & \multicolumn{2}{c|}{ Factor loads } & \multicolumn{1}{c|}{$\begin{array}{c}\text { Average coeffi- } \\
\text { cient(AVE) }\end{array}$} & Variable \\
\hline 0.72 & 0.75 & 0.84 & - & - & 0.643 & Organizational silence) OS( \\
- & - & - & 53.902 & 0.903 & & Defensive silence \\
- & - & - & 6.597 & 0.723 & & Obedient silence \\
- & - & - & 16.259 & 0.768 & & Altruistic silence \\
\hline
\end{tabular}

* Corresponding Author: Email: Bahman_saeidipour@yahoo.com

Received: 3 Jan 2021

Accepted: 10 Feb 2021 


\begin{tabular}{|c|c|c|c|c|c|c|}
\hline 0.78 & 0.88 & 0.91 & - & - & 0.663 & $\frac{\text { Organizational mobbing) OM( }}{\text { Threat to professional status }}$ \\
- & - & - & 35.249 & 0.861 & & Threat to personal integrity \\
- & - & - & 12.024 & 0.737 & & Isolation \\
- & - & - & 14.482 & 0.793 & & Work too much \\
- & - & - & 190.094 & 0.834 & & Instability \\
- & 0.80 & 0.83 & - & - & 0.623 & $\underline{\text { Turnover intention }}$ \\
\hline 0.70 & & & & & & TI( \\
\hline
\end{tabular}

Table 2: The correlation matrix and divergent validity

\begin{tabular}{|c|c|c|c|c|}
\hline \multicolumn{1}{|c|}{ Variable } & Organizational silence & Organizational Mobbing & & 0.80 \\
\hline Organizational silence & 1 & 1 & & 0.81 \\
\hline Organizational mobbing & 0.746 & 0.759 & 1 & 0.79 \\
\hline Turnover intention & 0.165 & & & . \\
\hline
\end{tabular}

\section{Results}

To analysis and evaluation of the model for this study, structural equation model has been used. Structural equation modeling is a statistical model for linear relationships between latent variables (unobserved) and manifest variables (observed). In other words, structural equation modeling is a powerful statistical technique that combines measurement model (confirmatory factor analysis) and structural model (regression or path analysis) with a statistical test at the same time. Through these techniques, researchers can reject hypothetical structures (models) or approve their compliance with data. In this research, SMARTPLS software was used for analysis. This software analyzes structural equation models that include multiple variables and direct, indirect and interactivity effects. This software is appropriate for Testing Moderating Effects (43). A study reported that the path models of PLS are estimated in two stages [44].

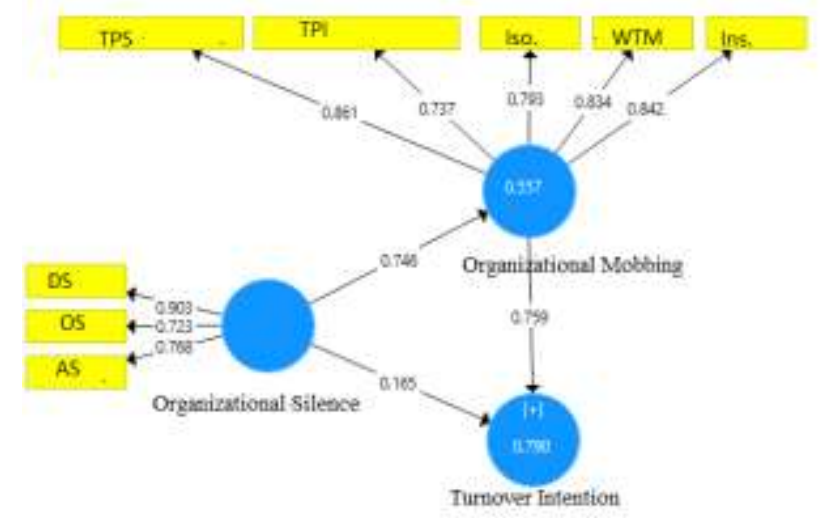

\section{Figure 2: Model structural coefficients}

The first stage estimates the score of the hidden variables for each latent variable and in the second stage, the moderating role of latent variables is studied depending on their status in the path model. Due to the nature of the second stage, many of the recommendations for the Testing Moderating Effects of multiple regressions are through SMARTPLS software. In the following, the outputs of the software and their analysis are given.

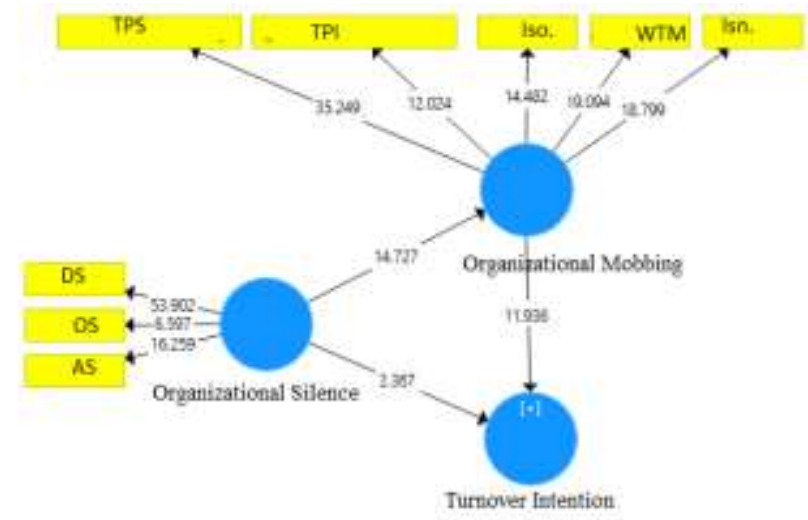

Figure 3: T-test results

Notably, the t-value shows the significant interaction effect of variables. If $\mathrm{t}$-value is greater than 1.96, then there is a positive and significant effect. If $\mathrm{t}$-value is between +1.96 and -1.96 , then there is not significant effect and if it is lower than -1.96, then there is negative and significant effect, also, if the path coefficients are above 0.6 , it means that 
there is a strong relationship between the two variables. If they are between 0.3 and 0.6 , there is a moderate relationship, and if they are below 0.3, there is a weak relationship (Chen, 2003). The data obtained from field research were conducted in
SMART PLS software and the above results were obtained in accordance with figures 2 and 3 . The analysis of each relationship, which in fact reflects the research hypotheses, is briefly shown in table 3.

Table 3: Results summary of the hypotheses test

\begin{tabular}{|c|c|c|c|c|c|}
\hline & Path & Impact rate & Significant level & Coefficient \\
\hline Organizational Silence $\longrightarrow$ Organizational Mobbing & Strong & Significant & 14.727 & 0.746 \\
\hline Organizational Mobbing $\rightarrow$ Turnover Intention & Strong & Significant & 11.936 & 0.759 \\
\hline Organizational Silence $\rightarrow$ Turnover Intention & Weak & Significant & 2.367 & 0.165 \\
\hline
\end{tabular}

According to table 3 that is obtained based on the results of the test hypotheses, it can be concluded that the result of first hypothesis test according to the path coefficient value 0.746 and t-test value 14.727 shows that the organizational silence has significant and strong impact on the organizational mobbing. In the second hypothesis with path coefficient value 0.759 and t-test value 11.936, the result shows that the organizational mobbing have positive and significant impact on the turnover intention. The results of the third hypothesis test with path coefficient value 0.165 and t-test value 2.367 shows that organizational silence has significant and weak impact on the turnover intention. It is necessary to present the total, direct and indirect effects for endogenous variables of the model to investigate the rate of direct and indirect effect of independent variables on the dependent variables (table 4).

Table 4: Separation of total, direct and indirect effects

\begin{tabular}{|c|c|c|c|}
\hline Relationships & Total effects & Indirect effects & Direct effects \\
\hline Organizational silence $\longrightarrow$ Organizational mobbing & 0.746 & ---- & 0.746 \\
\hline Organizational mobbing $\rightarrow$ Turnover intention & 0.759 & ---- & 0.759 \\
\hline Organizational silence $\rightarrow$ Turnover intention & 0.721 & 0.556 & 0.165 \\
\hline
\end{tabular}

As table 4 shows, organizational silence has a direct and significant effect on organizational mobbing, and this shows that organizational silence is able to predict the value 0.746 for organizational mobility. Also, organizational mobbing has a direct and significant effect on turnover intention, and this shows that organizational mobbing is able to predict the value 0.759 for turnover intention. Finally, organizational silence has a direct and significant effect on turnover intention, which also shows that organizational silence is able to predict the value 0.165 for turnover intention. According to the obtained results, it can be concluded that the mediating role of organizational mobbing in the effect of organizational silence on turnover intention has been supported. In other words, the indirect effect of organizational silence on turno- ver intention in the presence of the role of organizational mobbing (indirect effect $=0.555$ ) is greater than the direct effect of organizational silence on turnover intention (direct effect $=0.165$ ). In other words, considering the total effect (0.721) of organizational silence on turnover intention, it can be concluded that organizational silence with the help of organizational mobbing mediating variable has a better predictive effect on turnover intention. Therefore, the fourth hypothesis of this research was also confirmed.

\section{Model Processing}

Two models were tested in PLS models. Outer model which is equivalent to the measurement model and inner model which is equivalent to the structural model in other software models (LISREL, EQS, AMOS); the external model (measurement) is a model that determines the relationship 
between latent variables and explicit and observed variables. To fit this model, the Cross Validated Communality (an indicator used to check the fit of a "latent variables" block measurement model) is used. Also, the internal (structural) model is a model that determines the relationship between latent variables and for the fit of the structural model, the Cross Validated Redundancy (StoneGeiser coefficient $\mathrm{Q}^{2}$ ) has been used. This index predicts the indicators of endogenous latent variables $\left(\mathrm{R}^{2}\right)$. If these two indicators (Cross Validated Redundancy and reliability Communality) are positive, it indicates the appropriate quality of the structural model. However, as shown in Table 5, both indicators are positive and this shows that the model has the right quality. The value of $\mathrm{R}^{2}$, which indicates the ability of the model to describe the structure, is equal to 0.552 for 0.759 . Also, the value of $\mathrm{R}^{2}$ for turnover intention when Organizational Mobbing has a mediating role equal to 0.785. Finally, these results show that the presented model is an appropriate fit.

Table 5. Model fitting

\begin{tabular}{|l|l|l|l|}
\hline & $\begin{array}{l}\text { Variable } \\
\text { model } \\
\text { Validated } \\
\text { Redundancy }\end{array}$ & $\begin{array}{l}\text { Measurement } \\
\text { model } \\
\text { Reliability } \\
\text { Communality }\end{array}$ & $\mathbf{R}^{2}$ \\
\hline $\begin{array}{l}\text { organizational si- } \\
\text { lence }\end{array}$ & - & 0.300 & - \\
\hline $\begin{array}{l}\text { organizational mob- } \\
\text { bing }\end{array}$ & 0.333 & 0.471 & 0.552 \\
\hline $\begin{array}{l}\text { Turnover intention } \\
\text { In the presence of } \\
\text { organizational mob- } \\
\text { bing }\end{array}$ & 0.454 & 0.262 & 0.785 \\
\hline
\end{tabular}

\section{Discussion}

As mentioned, the purpose of this study was to investigate the role of organizational silence and Organizational Mobbing on turnover intention at Payam-e-Noor University in Kermanshah province. The results of the first hypothesis showed that organizational silence has an effect on organizational mobbing. This result is consistent with the results obtained in (11- 13 and 28, 30). Organizational silence is one of the most important factors in promoting or deterrence activities knowledge exchange. Therefore, due to the importance of organizational silence, through Organizational Mobbing, the necessary tools can be provided to facilitate the exchange of knowledge so that organizations can keep and share them, while the high volume of information which is exchanged in the organization. Therefore, Payame Noor University should pay enough attention to the role of "organizational silence" to be able to influence on Organizational Mobbing to manage knowledge in the organization.

The results obtained in the second hypothesis further indicate that Organizational Mobbing has an effect on turnover intention. This result is consistent with the results obtained in $(12,16,28,30)$ Confirming this hypothesis, it should be said that today the world is called the world of organizations and their trustees are considered human beings because human resources are the most valuable resource for organizations. Therefore, paying attention to this source should be of great importance, as every employee in the organization to achieve organizational goals, should be motivated and be properly aroused. That is experts in organizational behavior science believe that the root of the failures and successes depend on reducing the mobility of that organization, because it affects the tendency of employees to turnover intention in the negative direction. This statement proves that reduction of organizational mobbing can reduce turnover intention, so the relevant university should be able to pay enough attention to this in order to reduce turnover intention and increase the productivity of human resources.

The results of the third hypothesis also indicate the fact that organizational silence affects turnover intention. This result is consistent with the results obtained in $(12,25-30)$. Therefore, in confirming this hypothesis, it should be said that in today's organizations, organizational silence can be the dough for the development of human resources in the organization, because sometimes, this factor can lead to a decrease in turnover intention, and since human beings are the center of productivity, the managers of today's organizations need to reduce turnover intention. It can be said that good 
human resources are able to increase the competitive advantage of the organization in which they work. In this way, organizational silence can help human resources so that employees learn how they can reduce turnover intention so that they can achieve both "competitive advantage" and increase the productivity of their system. Therefore, the relevant university should use the importance of the role that organizational silence has in this field, in order to achieve a competitive advantage. The results of the fourth hypothesis also stated that Organizational Mobbing has a mediating role in the effect of organizational silence on turnover intention. Confirming the second hypothesis, it should be said that Organizational Mobbing is a new topic which has recently entered the science of psychology and management and in the field of organizational behavior. As human resources are the main and irreplaceable assets of the organization, so that the success and survival of the organization depends on them. Therefore, the employees of the organization should be warned against mobbing, in order to reduce turnover intention. Also, considering the confirmation of the third research hypothesis "The effect of organizational silence on turnover intention", it can be hoped that considering the positive effects which Organizational Mobbing has on the tendency to leave the organization, the effects of organizational silence on turnover intention can be doubled.. Therefore, the relevant university should pay enough attention to the importance of the role of Organizational Mobbing in order to be able to increase the effects which organizational silence can have on turnover intention.

Finally, considering the results of the structural equation model, it can be said that this conceptual model of research can be used as an experimental model that can be a guide and basis for future scientific and practical research. However, according to the above results, the limitation that the researchers faced in this study was that employees (scientific and administrative) have fear from the subject that answer to the questions may have a negative effect on their job, the questions may have responded conservatively.

\section{Conclusion}

Organizational silence is directly related to employee behavior in order to increase or decrease individual and organizational performance. Thus, universities can take an effective step towards overcoming the employees' fears that they face in the workplace by reducing the burden of organizational silence in a positive direction. By doing so, employees are less likely to think about leaving their jobs in the workplace. On the other hand, according to the fact that, the role of organizational mobbing in the relationship between the above variables (organizational silence and the desire to leave the job) was confirmed in this study, therefore, university administrators can pay special attention to the role of the mediating variable (organizational mobbing) in order to reduce the job leaving.

\section{Ethical Consideration}

Ethical issues (such as plagiarism, conscious satisfaction, misleading, making and or forging data, publishing or sending to two places, redundancy and etc.) have been fully considered by the writers.

\section{Acknowledgement}

Researchers consider it necessary to thank and appreciate all the participants who helped us in this research.

\section{References}

1. Morrison EW, Milliken FJ (2000). Organizational silence: a barrier to change and development in a pluralistic world. Academy of Management Revien, 25: 706-25.

2. Milliken FJ, Morrison EW, Hewlin PF (2003). An expletory study of employee silence: issues that employees don't communicate upward and why. Journal of Management Studies, 40(6): 1453-1476.

3. Leymann H (1996). The content and development of bullying at work. European Journal of Work and Organizational Psychology, 5: 165-184. 
4. Irvine DM, Evans MG (1995). Job satisfaction and turnover among nurses: Integrating research findings across studies. Nurs Res JulAug, 44 (4): 246-53

5. Shuck B, Twyford D, Reio TG, Shuck A (2014). Human resource development practices and employee engagement: Examining the connection with employee turnover intentions. Human Resource Development Quarterly, 25(2): 239270.

6. Minibas-Poussard J, Bingöl HB, Celik TS (2018). Mobbing in higher education: descriptive and inductive case narrative analyses of mobbed behavior, mobbed responses, and witness support. Educational Sciences: Theory and Practice, 18(2): 471-494.

7. Vega G, Ve Comer DR (2005). Sticks and stones may break your bones, but words can break your spirit: Bullying in the workplace. Journal of Business Ethics, 58: 101-109.

8. Bedük A, Eryeşil K, Duran Altunısık G (2017). The relationship between mobbing and organizational cynicism: An empirical study. Journal of Human Sciences, 14(4): 31673176.

9. Keashly L, Neuman JH (2010). Faculty experiences with bullying in higher education: causes, consequences, and management. Administrative Theory \& Praxis, 32 (1): 48-70

10. Erdirencelebi M, Şendogdu A (2016). Effects of mobbing and organizational silence on employee's performance. The Macrotheme Review, 5(5): 101-116.

11. Hüsrevşahi SP (2015). Relationship between organizational mobbing and silence behavior among teachers. Educational Sciences: Theory and Practice, 15(5): 1179-1188

12. Elçi M, Karabay ME, Alpkan L, Şener I (2014). The mediating role of mobbing on the relationship between organizational silence and turnover intention. Procedia - Social and Behavioral Sciences, 150 (2014): 1298 - 1309.

13. Yüceler $A$, ùahin $E$, ùahin $ø E$, Demirsel MT (2013). The relationship between mobbing and organizational silence in establishments. Humanities and Social Sciences Review, 2(1):153-161.

14. Hogh A, Hoel H, Carneiro IG (2011). Bullying and employee turnover among healthcare workers: a three wave prospective study. Journal of Nursing Management, 19(6): 742751.

15. Berthelsen M, Skogstad A, Lau B, Einarsen S (2011). Do they stay or do they go? A longitudinal study of intentions to leave and exclusion from working life among targets of workplace bullying. International Journal of Manpowver, 32(2): 178-193.

16. Cinar O (2015). The relationships between mobbing, organizational citizenship behavior and turnover intention: a survey study in Erzurum/Turkey. Journal of Global Strategic Management, 9 (1): 87-98.
17. McCormack D, Casimir G, Djurkovic N, Yang L (2009). Workplace bullying and intention to leave among schoolteachers in china: the mediating effect of affective commitment. Journal of Applied Social Psycbology, 39(9): 2106-2127.

18. Kuvaas B (2006). Performance appraisal satisfaction and employee outcomes: mediating and moderating roles of work motivation. International Journal of Human Resource Management, 17(3): 504522.

19. Hwang IS, Kou JH (2006). Effects of job satisfaction and perceived alternative employment opportunities on turnover intention: an examination of public sector organizations. Journal of American Academy of Business, 8(2): 254255.

20. Alparslan AM (2010). Örÿ̈tsel sessizllik ik limi ve isgören sessiz̨lik dauramslan arasmdaki etkilesim: mehmet akif ersoy üniversitesi ögretim elemanlar üzerinde bir arasstrma. Süleyman Demirel Üniversitesi Sosyal Bilimler Enstitüsü, İşletme Anabilim Dalı, Yüksek Lisans Tezi. (In Turkey).

21. Acaray A, Gunduz ÇH, Akutran A (2015). Örgüt kültürü ile örgütsel sessizlik arasındaki ilişkinin incelenmesi. The Jounnal of Academic Social Science Studies, 32(3):139-157. (In Turkey).

22. Souba W, Way D, Lucey C, Sedmak D, Notestine M (2011). Elephants in academic medicine. Acad Med, 86(12):1492-9.

23. Johannesen R L (1974). The functions of silence: A plea for communication research. Western Speech Journal, 2 (29): 25-35.

24. Özdemir L, Uğur SS (2013). Çalışanlarnn örgütsel ses ve sessizlik algilamalarının demografik nitelikler açısından değerlendirilmesi: kamu ve özel sektörde bir araşurma. Atatïrk Üniversitesi İktisadi ve İdari Bilimler Dergisi, Cilt, 27 (1): 257-280. (In Turkey).

25. Wang FF (2012). Employee silence and turnover intention. [MA Thesis]. University of China, China.

26. Chung HS, Ha HK, Kun PD (2010). The influence of organizational silence on turnover intention: mediated moderating effect of self-efficacy through organizational cynicism. The Korean Journal of Industrial and Organizational Psychology, 23(1): 89 - 104.

27. Salimian MA, Krosian Z (2017). Investigating the relationship between organizational silence and job leave of employees of the general administration of ports and maritime affairs of mazandaran province. $2^{\text {nd }}$ Annual Conference on Economics, Management, and Accounting. Shahid Chamran University, Khuzestan / Iran (in Persian)

28. Soltani T, Masrati A (2017). Sources of the relationship between organizational silence and the intention to leave the job of employees and the mediating role of stress in Khurestan Gas Company. Shushtar University of Applied Sciences, Shiraz/ Iran. (In Persian) 
29. Razavian SB, Mohammadzadeh Z (2015). The effect of organizational silence events on fuzzy delphi turnover intention. International Conference on Management Critique and Analysis in the Third Millennium, Mashhad/ Iran. (In Persian)

30. Hoshyar V, Rahimi Qara Chamak M (2015). The effect of organizational silence on Turnover Intention to Mediator of the emotional attack among employees of non-profit and non-governmental higher education institutions in Mashhad. Farda Management Joumal, 13 (45): 152-141. (In Persian)

31. Tetik S (2010). KMÜ Sosyal ve Ekonomik Araşturmalar. Dergisi, 12 (18): 81-89. (In Turkey).

32. Aldığ E (2011). İş yerinde yıldırma (mobbing) ve ömek bir çalışma. Yayımlanmamış Yükseklisans Tezi, Doğuş Üniversitesi, Turkey. (In Turkey).

33. Carnero A, Blanca M, Rocío SM (2012). Mobbing and workers' health: empirical analysis for Spain. International Journal of Manpower, 33(3): 322-339.

34. Bjørkelo B (2013). Workplace bullying after whistle blowing: future research and implications. Journal of Management Psychology, 28(3): 306-323.

35. O'Moore M, Crowley N (2011) The clinical effects of workplace bullying: a critical look at personality using SEM. International Journal of Workplace Health Management, 4(1): $67-83$.

36. Garvois J (2006). Mob rule: in departmental disputes, professors can act just like animals. Chron. Sec Fac, 52(32).
37. Martino VD, Hoel H, Cooper CL (2003). Preventing violence and harassment in the workplace. European Foundation for the Improvement of Living and Working Conditions, Dublin/Ireland.

38. BarlingJ, Rogers AG, Kelloway EK (2001). Behind closed doors: In-home workers' experience of sexual harassment and workplace violence. Journal of Occupational Health Psychology, 6(3): 225-269.

39. Taş A, Ergeneli A, Akyol A, Demirel H (2013). Mobbing ile tükenmişlik arasmdaki iliskide öngütsel sessiz̨liğn etkisi. Örgütsel Davranış Kongresi , Sakarya/ Turkey. (In Turkey).

40. Einarsen S, Mikkelsen EG (2003). Individual effects of exposure to bullying at work. Bullying and emotional abuse in the workplace. International Perspectives In Research And Practice, 127.

41. Dostar M, Esmailzadeh M (2013). Organizational justice and its impact on employee voice and performance. Quarterly Journal of Improvement and Transformation Management Studies, 22(72): 143-163. (In Persian)

42. Pranjić N, Maleš-Bilić L, Beganlić A, Mustajbegović J (2006). Mobbing, stress, and work ability index among physicians in Bosnia and Herzegovina: Survey Study. Croatian Medical Journal, 47(5): 750-758.

43. Fornell C, Larcker D (1981). Evaluating structural equation models with unobservable variables and measurement error. Journal of Marketing Research, 18 (1): 39-50.

44. Esposito Vinzi V, Chin W, Henseler J, Wang H (2010). Handbook of partial least squares: concepts, methods and applications, computational statistics handbook series .Vol. II. Springer, Germany. 